\title{
Chromosomal location of powdery mildew resistance genes in Triticum aestivum $L$. (common wheat). 2. Genes Pm2 and Pm19 from Aegilops squarrosa $\mathrm{L}$.
}

\author{
J. LUTZ, S. L. K. HSAM, E. LIMPERT† \& F. J. ZELLER* \\ Technische Universität München, Institut für Pflanzenbau und Pflanzenzüchtung, D-85350 Freising-Weihenstephen, \\ Germany and †institut für Pflanzenwissenschaften, 8092 Zürich, Switzerland
}

\begin{abstract}
Two mildew resistant accessions of diploid Aegilops squarrosa and their hexaploid synthetics derived from crosses with mildew susceptible Triticum durum cultivars were tested with differential isolates of Erysiphe graminis f. sp. tritici and their responses were compared with the response patterns of 16 wheat cultivars or lines possessing known mildew resistance genes. Resistance in the A. squarrosa accession 'Braunschweig BGRC 1458' was conditioned by the dominant gene Pm2. This gene confers the same response pattern with a set of mildew isolates when present at the diploid species level or in a hexaploid synthetic with $T$. durum. It was located on wheat chromosome 5D. The resistance gene in the A. squarrosa accession 'Gatersleben AE 457/78' showed a different response pattern in the hexaploid synthetic line ' $\mathrm{XX}$ 186' tested with mildew isolates compared with that of the diploid. Its response pattern was also different from all other wheats with named genes for resistance to powdery mildew. The gene, localized on chromosome 7D in the synthetic 'XX 186', was designated Pm19.
\end{abstract}

Keywords: Aegilops squarrosa, powdery mildew, resistance genes, synthetic amphiploid wheats, Triticum aestivum.

\section{Introduction}

Several examples of successful transfers of genes for resistance to powdery mildew caused by Erysiphe graminis $\mathrm{f}$. sp. tritici from cultivated and wild relatives of Triticum to commercial bread wheat have been reported. Genes Pm4a and Pm5 from Triticum dicoccum (Briggle, 1966; Law \& Wolfe, 1966) and Pm $4 b$ from $T$. carthlicum were transferred from the tetraploid level to hexaploid common wheat (The et al., 1979). Gene Pm6 in several bread wheat cultivars traces to Triticum timopheevii (Jørgensen \& Jensen, 1972) and gene Pml6 to T. dicoccoides (Reader \& Miller, 1991). Gene Pm12 originated from Aegilops speltoides (Miller et al., 1988) and Pml3 from A. longissima (Zeller \& Heun, 1985; Ceoloni et al., 1992). In addition, four designated genes, $P m 7, P m 8, P m 17$ and $P m 20$, in common wheat, were derived from cultivated rye, Secale cereale (Driscoll \& Anderson, 1967; Zeller, 1973; Zeller \& Fuchs, 1983; Heun \& Friebe, 1990; Friebe et al., 1994). Finally, gene Pm21 traced to

*Correspondence.
Dasypyrum villosum (Qi et al., in press; P. D. Chen, personal communication). Thus several genes from relatives of wheat are presently being utilized in commercial resistance breeding. Furthermore, there is a tremendous potential in many other perennial species of the Triticeae resistant to powdery mildew waiting to be used for the improvement of disease resistance in common wheat (Wang et al., 1993).

Aegilops squarrosa $(2 n=14)$ which shares the D genome with Triticum aestivum is also a potential donor of numerous beneficial genes to cultivated wheat (Lutz et al., 1994). The transfer of genes into hexaploid wheat is relatively easy as the chromosomes of the diploid species pair readily with those of the $D$ genome of Triticum aestivum. Mains (1933) first reported on the resistance of $A$. squarrosa to wheat powdery mildew. Later Pasquini (1980), Frauenstein \& Hammer (1985), Gill et al., (1986), Valkoun et al. (1985, 1990) and Cox et al. (1992) confirmed A. squarrosa as a potential source of mildew resistance. Tosa \& Sakai (1991) found that $A$. squarrosa also possesses resistance genes (PmIO and Pm15) to Erysiphe graminis f. sp. agropyri, the wheatgrass mildew fungus. Recently, Lutz 
et al. (1994) described several mildew resistances that were transferred from $A$. squarrosa to common wheat. The present study reports on the chromosomal location of two resistance genes $P m 2$ and $P m 19$ in synthetic wheat lines by monosomic analysis and allelism tests.

\section{Materials and methods}

The Aegilops squarrosa accession 'BGRC 1458' was obtained from the gene bank at Braunschweig, Germany, and accession 'AE 457/78' from the gene bank at Gatersleben, Germany. The latter was originally from Georgia (former USSR). The mildew susceptible Triticum durum cultivars 'Moroccos 182' and 'Santa Marta' were provided by A. Zeven, The Netherlands. The $A$. squarrosa accessions were crossed as male parents to $T$. durum cultivars 'Moroccos 182' and 'Santa Marta'. Embryos of the $F_{1}$ hybrids were rescued and the plantlets treated with colchicine. The synthetic wheat lines ' $\mathrm{XX} \mathrm{186'} \mathrm{(} T$. durum 'Santa Marta' $\times$ A. squarrosa 'BGRC 1458') and 'XX 194' $\left(T\right.$. durum 'Moroccos $183^{\prime} \times A$. squarrosa 'AE 457/78') were selected on the basis of their response pattern from the synthetic wheat lines described by Lutz et al. (1994). The 'Chinese Spring' monosomic lines used for gene location were originally obtained from E. R. Sears, USA. Mildew isolate no. 10 known to be avirulent to synthetic lines 'XX 186' and 'XX 194' (Table 1; Lutz et al., 1994) was used to test segregating $F_{2}$ populations. Segments of primary leaves of host plants were placed in Petri dishes on agar $(6$ $\mathrm{g} / \mathrm{L})$ and $35 \mu \mathrm{g} / \mathrm{g}$ benzimidazole. The detailed methods for inoculation of leaf segments and disease assessments were described in Zeller et al. (1993).

\section{Results}

\section{Response of synthetic wheat lines ' $X X 186^{\prime}$ and ' $X X$} $194^{\prime}$ and other wheat cultivars/lines to mildew

The response pattern of 15 wheat cultivars/lines

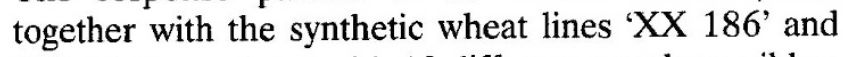
'XX 194' inoculated with 12 different powdery mildew isolates are listed in Table 1. Line 'XX 186' was resistant to six isolates, gave an r, i-response to one and was intermediate to susceptible in response to four isolates, thus differing from all other wheats tested (Table 1). However, its diploid $A$. squarrosa parent was resistant to all tested mildew isolates (Lutz et al., 1994). In comparison with the reaction of cultivars or lines possessing known mildew resistance genes, synthetic 'XX 194' developed by hybridization with a mildew susceptible $T$. durum cultivar showed an identical pattern to that of 'Ulka/8*Cc'.

\section{Chromosomal location of the resistance genes in synthetic lines ' $X X 186^{\prime}$ and ' $X X 194$ '}

$\mathrm{F}_{2}$ populations from crosses of the $\mathrm{D}$ genome monosomics (1D-7D) with 'XX 186' and 'XX 194' were inoculated with mildew isolate no. 10 avirulent to both host lines. Most of the populations of each combination segregated in a ratio of three resistant to one susceptible (Table 2). In line 'XX 186' the results from monosomic 7D and in line 'XX 194' from monosomic $5 \mathrm{D}$ deviated significantly $(P<0.01)$ from the expected ratio. Although crosses involving mono-4D and mono$7 \mathrm{D} \times$ 'XX 194' gave an unexpected high number of susceptible plants, the data indicated that the resistance genes in lines 'XX 186' and 'XX 194' are located on chromosomes 7D and 5D, respectively. The locus on chromosome 7D, for which no mildew resistance gene is known so far, was designated $P m 19$.

\section{Allelism tests with synthetic line 'XX 194' and near- isogenic line 'Ulka/8* Cc'}

For allelism tests, 'XX 194' was crossed to the nearisogenic line 'Ulka/ $8{ }^{*} \mathrm{Cc}$ ' which possesses gene $\mathrm{Pm} 2$. All $193 \mathrm{~F}_{2}$ plants tested with isolates no. 5, 6, 10 and 15 were resistant confirming that both ' $\mathrm{XX} 194$ ' and line 'Ulka $/ 8 * \mathrm{Cc}$ ' have the same resistance gene.

\section{Discussion}

The data presented indicate that the gene responsible for mildew resistance in synthetic ' $\mathrm{XX} 194$ ' is $\mathrm{Pm} 2$. Firstly, the response pattern with several mildew isolates was identical with that of the near-isogenic line 'Ulka/*8Cc' (Table 1) known to possess Pm2 (Briggle, 1969). Secondly, the monosomic analysis with ' $X X$ 194' clearly showed the location of the resistance gene on chromosome 5D which is in accordance with the results of McIntosh \& Baker (1970) concerning Pm2. Thirdly, the $F_{1}$ progenies from the hybrid between ' $X X$ 194 ' and line 'Ulka/*8Cc' were uniformly resistant to a $\mathrm{Pm}$ 2-avirulent isolate indicating identical resistance genes.

Nyquist (1963) found in the T. timopheevii derivative 'C.I. 12633' a dominant mildew resistance gene, designated $M 1_{\mathrm{x}}$ which was effective in the early seedling stage. Allard \& Shands (1954) suggested that the resistance gene from $T$. timopheevii has been transferred to 'C.I. 12633'. Furthermore, Pugsley \& Carter (1953) described 'Ulka' as a mildew resistant cultivar that was introduced by a farmer from Russia into the USA. In the $F_{1}$ progeny of test crosses between 'Ulka' and 'C.I. 12632', a sister line of 'C.I. 12633', inoculated with two mildew isolates, no susceptible segregate was observed (Briggle, 1969). As the near-isogenic lines 
Table 1 Differential reactions of 16 wheat cultivars/lines possessing powdery mildew resistance genes inoculated with 12 isolates of Erysiphe graminis f. sp. tritici

\begin{tabular}{|c|c|c|c|c|c|c|c|c|c|c|c|c|c|}
\hline \multirow[b]{2}{*}{ Cultivar/Line } & \multirow{2}{*}{$\begin{array}{l}\text { Res.gene } \\
\quad(P m)\end{array}$} & \multicolumn{12}{|c|}{ Erysiphe graminis tritici isolate no. } \\
\hline & & 2 & 5 & 6 & 9 & 10 & 12 & 13 & 14 & 15 & 16 & 17 & 20 \\
\hline Axminster $/ 8^{*} \mathrm{Cc} \dagger$ & 1 & $\mathbf{r}$ & s & $\mathrm{r}$ & $\mathbf{i}, \mathbf{s}$ & $\mathbf{r}$ & $\mathbf{s}$ & s & $\mathbf{s}$ & $\mathbf{r}$ & $\mathbf{s}$ & $\mathbf{s}$ & $\mathbf{s}$ \\
\hline Ulka $/ 8^{*} \mathrm{Cc} \dagger$ & 2 & s & $\mathbf{r}$ & $\mathbf{r}$ & $\mathbf{s}$ & $\mathbf{r}$ & $\mathbf{s}$ & s & $\mathbf{s}$ & r & $\mathbf{s}$ & $\mathbf{s}$ & s \\
\hline Asosan $/ 8^{*} \mathrm{Cc} \dagger$ & $3 a$ & $\mathrm{r}$ & $\mathbf{s}$ & $\mathbf{r}$ & $\mathbf{r}$ & $\mathrm{r}$ & $\mathbf{s}$ & r & $\mathrm{r}$ & $\mathbf{s}$ & $\mathbf{s}$ & $\mathrm{i}$ & $\mathbf{r}$ \\
\hline $\mathrm{Chul} / 8^{*} \mathrm{Cc} \dagger$ & $3 b$ & $r$ & s & s & $r$ & $\mathrm{r}$ & $r$ & $\mathrm{r}$ & $r$ & s & $\mathbf{r}$ & i,s & $\mathbf{r}$ \\
\hline Sonora $/ 8^{*} \mathrm{Cc} \dagger$ & $3 c$ & $\mathbf{r}$ & s & s & $\mathrm{i}$ & $\mathbf{r}$ & $\mathbf{s}$ & $\mathbf{r}$ & i,s & $\mathbf{s}$ & $\mathbf{s}$ & $\mathbf{S}$ & $\mathbf{s}$ \\
\hline Kolibrił & $3 d$ & $\mathbf{s}$ & s & s & $\mathbf{r}$ & $\mathbf{s}$ & $\mathrm{r}$ & s & $\mathrm{r}$ & $\mathrm{r}$ & $\mathbf{s}$ & $\mathbf{r}$ & $\mathbf{s}$ \\
\hline Khapli/8*Cc $\dagger$ & $4 a$ & $\mathrm{~s}$ & $\mathrm{r}$ & s & $r$ & $\mathrm{i}$ & $r$ & s & $\mathbf{s}$ & i & s & $\mathrm{i}$ & s \\
\hline Armada & $4 \mathrm{~b}$ & $\mathrm{~s}$ & $\mathrm{r}$ & $\mathbf{s}$ & $\mathrm{r}$ & $\mathrm{r}$ & $\mathbf{r}$ & s & s & $\mathbf{r}$ & s & s & $\mathbf{s}$ \\
\hline Hope & 5 & $\mathbf{s}$ & s & s & $\mathrm{s}$ & $r$ & $\mathbf{S}$ & s & $r$ & s & s & $\mathbf{s}$ & $\mathbf{s}$ \\
\hline TP $114 /$ St. $2 \S$ & 6 & $\mathrm{~s}$ & $\mathrm{r}, \mathrm{i}$ & $\mathrm{r}, \mathrm{i}$ & $\mathbf{r}$ & $\mathrm{r}, \mathrm{i}$ & $\mathbf{s}$ & $\mathrm{r}, \mathrm{i}$ & $\mathrm{r}, \mathrm{i}$ & $\mathrm{r}, \mathrm{i}$ & $\mathrm{i}$ & $\mathbf{s}$ & $\mathbf{s}$ \\
\hline Disponent & 8 & $r$ & s & s & $\mathbf{r}$ & $\mathbf{s}$ & $\mathrm{r}$ & s & $\mathbf{s}$ & $\mathbf{s}$ & $\mathbf{s}$ & $r$ & $\mathbf{s}$ \\
\hline Normandie & $1+2+9$ & $r$ & $\mathrm{r}$ & $r$ & $r$ & $r$ & $\mathbf{s}$ & $s$ & s & $\mathrm{r}$ & $s$ & $\mathbf{s}$ & $\mathbf{r}$ \\
\hline BRG 3N§§ & 16 & $\mathrm{r}$ & $\mathrm{r}$ & $\mathrm{r}$ & r & $\mathrm{r}$ & $\mathbf{r}$ & $\mathrm{r}$ & $r$ & $r$ & $\mathrm{r}$ & $\mathbf{r}$ & 1 \\
\hline Amigo & 17 & $\mathrm{i}$ & $\mathrm{i}$ & $\mathrm{i}, \mathrm{s}$ & $\mathrm{i}$ & $\mathrm{i}$ & $\mathrm{i}$ & $r$ & s & $\mathrm{i}$ & $\mathbf{r}$ & $\mathrm{r}, \mathrm{i}$ & 1 \\
\hline XX 194 & 2 & s & $r$ & $r$ & $s$ & $\mathbf{r}$ & $s$ & $\mathbf{S}$ & $s$ & $\mathbf{r}$ & $s$ & $\mathbf{s}$ & $\mathbf{s}$ \\
\hline XX 186 & 19 & s & $s$ & $\mathbf{r}$ & $r$ & $\mathbf{r}$ & $\mathbf{r}$ & i,s & $\mathbf{r}$ & $s$ & $\mathrm{r}, \mathrm{i}$ & $\mathbf{r}$ & 1 \\
\hline
\end{tabular}

r: resistant; s: susceptible; i: intermediate; /: not tested.

$\dagger$ Eight times backcrossed to 'Chancellor'.

‡Data after Zeller et al. (1993).

$\S$ Twice backcrossed to 'Starke'.

$\S \S^{\mathrm{B} R G} 3 \mathrm{~N} / 76-\mathrm{F}_{2}-205^{\prime}$, a $T$. turgidum var. dicoccoides derivative.

Table 2 Segregation for seedling reaction to mildew isolate no. 10 in monosomic $F_{2}$ populations from crosses of seven 'Chinese Spring' monosomics (mono-1D to mono-7D) with the synthetic wheat lines 'XX 194' and 'XX 186'

\begin{tabular}{lcc}
\hline Chromosome involved & $\begin{array}{c}\text { Observed segregation } \\
\text { (resistant:susceptible) }\end{array}$ & $\chi^{2} 3: 1$ \\
\hline 1D $\times$ XX 194 & $86: 26$ & 0.19 \\
2D $\times$ XX 194 & $106: 37$ & 0.06 \\
3D $\times$ XX 194 & $138: 47$ & 0.02 \\
4D $\times$ XX 194 & $32: 23$ & $8.30^{* *}$ \\
5D $\times$ XX 194 & $92: 4$ & $22.22^{* *}$ \\
6D $\times$ XX 194 & $51: 19$ & 0.17 \\
7D $\times$ XX 194 & $37: 22$ & $4.75^{*}$ \\
Total excluding mono-5D hybrids & $450: 174$ & 2.77 \\
1D $\times$ XX 186 & $11: 3$ & 0.10 \\
2D $\times$ XX 186 & $33: 9$ & 0.29 \\
3D $\times$ XX 186 & $113: 40$ & 0.11 \\
4D $\times$ XX 186 & $27: 11$ & 0.32 \\
5D $\times$ XX 186 & $53: 13$ & 0.99 \\
6D $\times$ XX 186 & $87: 26$ & 0.24 \\
7D $\times$ XX 186 & $53: 5$ & $8.30^{* *}$ \\
Total excluding mono-7D hybrids & $324: 102$ & 0.25 \\
\hline
\end{tabular}

The synthetic lines 'XX 186' and 'XX 194' were resistant and cultivar 'Chinese Spring' susceptible.

${ }^{*} P<0.05,{ }^{* *} P<0.01$. 
'Ulka/*8Cc' and 'C.I. 12632/*8Cc' show identical response patterns, Briggle (1969) concluded that $\mathrm{Pm} 2$ and $M 1_{\mathrm{x}}$ are allelic. McIntosh \& Baker (1970) located $P m 2$ in 'Ulka' on the short arm of wheat chromosome 5D. The species $T$. timopheevii (genome formula: $A A G G, 2 n=14$ ) does not share genome $\mathrm{D}$ with common wheat $(A A B B D D, 2 n=6 \mathrm{x}=42)$. Therefore it is unlikely that $P m 2$ was derived from this tetraploid species. Already Pugsley (1961) had found $M 1_{x}(P m 2)$ in the Australian wheat selection 'Javelin-325' which received its resistance from Sears' $6 \mathrm{x}$ synthetic wheat, T. durum cv. 'Iumillo' $\times A$. squarrosa. 'Iumillo' is susceptible to mildew isolates not attacking the synthetic amphiploid (McIntosh \& Baker, 1970). A. squarrosa ssp. strangulata is proposed to be the D genome donor of hexaploid wheat (Jaaska, 1981; Lagudah \& Halloran, 1988). However, as Pm2 is widespread in diploid $A$. squarrosa accessions other than ssp. strangulata (Lutz et al., 1994) it is suggested that its presence in hexaploid wheats could have originated from other squarrosa subspecies. However, an independent occurrence of a spontaneous mutation which may have led to the $P m 2$ gene in cultivar 'Ulka' cannot be ruled out.

With regard to $P m 19$, so far no other powdery mildew resistance gene has been described that is located on chromosome 7D. It is known that $P m 1$ and Pm9 are located on chromosome 7AL (Sears \& Briggle, 1969; McIntosh, in press) and Pm5 on chromosome 7BL (Law \& Wolfe, 1966). Therefore it is possible that some of these genes are homoeo-alleles on wheat chromosomes of group 7 .

\section{Acknowledgements}

J. Lutz thanks the Gemeinschaft zur Förderung der privaten deutschen Pflanzenzüchtung, e.V., Bonn, for a fellowship (A 9/87 ZK). S. L. K. Hsam expresses his gratitude to Deutsche Forschungsgemeinschaft, Bonn, for financial support (Ze 132/14-1). We are very grateful to Heidrum Glöckner for excellent technical assistance.

\section{References}

ALLARD, R. W. AND SHANDS, R. G. 1954. Inheritance of resistance to stem rust and powdery mildew in cytologically stable spring wheats derived from Triticum timopheevii. Phytopathology, 44, 266-274.

BRIGGLE, L. W. 1966. Three loci in wheat involving resistance to Erysiphe graminis f. sp. tritici. Crop Sci., 6, 461-465.

BRIGGLE, L. W. 1969. Near-isogenic lines of wheat with genes for resistance to Erysiphe graminis f. sp. tritici. Crop Sci., 9, 70-72.
CEOLONI, C., DEL SIGNORE, G., ERCOLI, L. AND DONINI, P. 1992. Locating the alien chromatin segment in common wheat-Aegilops longissima mildew resistant transfers. Hereditas, 116, 239-245.

COX, T. S., RAUPP, W. J., WILSON, D. L., GILL, B. S., LEATH, S. AND BROWDER, L. E. 1992. Resistance to foliar diseases in a collection of Triticum tauschii germ plasm. Plant Disease, 76, 1061-1064.

DRISCOLL, C. J. AND ANDERSON, L. M. 1967. Cytogenetic studies of Transec - a wheat-rye translocation line. Can. J. Genet. Cytol., 9, 375-380.

FRAUENSTEIN, K. AND HAMMER, K. 1985. Prüfung von AegilopsArten auf Resistenz gegen Echten Mehltau, Erysiphe graminis DC., Braunrost, Puccinia recondita Rob. ex Desm., und Spelzenbräune, Septoria nodorum Berk. Kulturpflanze, 33, 155-163.

FRIEBE, B., HEUN, M., TULEEN, N., ZELLER, F. J. AND GILL, B. S. 1994. Cytogenetically monitored transfer of powdery mildew resistance from rye into wheat. Crop Sci., 34, 621-625.

GILL, B. S., RAUPP, W. J., SHARMA, H. C., BROUDER, L. E., HATCHETT, J. H., HARVEY, T. L., MOSEMAN, J. G. AND WAINES, J. G. 1986. Resistance in Aegilops squarrosa to wheat leaf rust, wheat powdery mildew, greenbug and Hessian fly. Plant Disease, 76, 553-556.

HEUN, M. AND FRIEBE, B. 1990. Introgression of powdery mildew resistance from rye into wheat. Phytopathology, 80, 242-245.

JAASKA, v. 1981. Aspartate aminotransferase and alcohol dehydrogenase isoenzymes: intraspecific differentiation in Aegilops tauschii and the origin of the D genome polyploids in the wheat group. Pl. Syst. Evol., 137, 259-273.

JøRGENSEN, J. H. AND JENSEN, C. J. 1972. Genes for resistance to wheat powdery mildew in derivatives of Triticum timopheevii and Triticum carthlicum. Euphytica, 21, 121-128.

LAGUDAH, E. S. AND HALloran, G. M. 1988. Phylogenetic relationships of Triticum tauschii, the D genome donor to hexaploid wheat. 1. Variation in HMW subunits of glutenin. Theor. Appl. Genet., 75, 592-598.

LAW, C. N. AND WOLFE, M. S. 1966 . Location for genetic factors for mildew resistance and ear emergence time on chromosome 7B of wheat. Can. J. Genet. Cytol. 8, 462-470.

LUTZ, J., HSAM, S.L.K., LIMPERT, E. AND ZELLER, F. J. 1994. Powdery mildew resistance in Aegilops tauschii Coss. and synthetic hexaploid wheats. Genet. Res. Crop Evol., 41, 151-158.

McINTOSH, R. A. Catalogue of gene symbols for wheat. In: Proceedings of 8th International Wheat Genetics Symposium, Beijing, China (in press).

McINTOSH, R. A. AND BAKER, E. P. 1970. Cytogenetical studies in wheat. IV. Chromosome location and linkage studies involving the $\mathrm{Pm} 2$ locus for powdery mildew resistance. Euphytica, 19, 71-77.

MAINS, E. B. 1933. Host specialization of Erysiphe graminis tritici. Proc. Natl. Acad. Sci. U.S.A., 19, 49-53.

MILLER, T. E., READER, S. M., AINSWORTH, C. C. AND SUMMERS, R. W. 1988. The introduction of a major gene for resistance to powdery mildew of wheat, Erysiphe graminis f. sp. tritici, from Aegilops speltoides into wheat, Triticum aestivum. In: 
Proceedings of the Conference Section EUCARPIA, pp. 179-183, Wageningen, The Netherlands.

NYQUIST, W. E. 1963. Inheritance of powdery mildew resistance in hybrids involving a common wheat strain derived from Triticum timopheevii. Crop Sci., 3, 40-43.

PASQUINI, M. 1980. Disease resistance in wheat. II. Behaviour of Aegilops species with respect to Puccinia recondita f. sp. tritici, Puccinia graminis f. sp. tritici, and Erysiphe graminis f. sp. tritici. Genet. Agr., 34, 133-148.

PUGSLEY, A. T. 1961. Additional resistance in Triticum vulgare to Erysiphe graminis tritici. Aust. J. Biol. Sci., 14, 70-75.

PUGSLEY, A. T. AND CARTER, M. V. 1953. The resistance of twelve varieties of Triticum vulgare to Erysiphe graminis tritici. Aust. J. Biol. Sci., 6, 335-346.

QI, L. L., CHEN, P. D., LIU, D. J., ZHOU, B. AND ZHANG, S. Z. Development of translocation lines of Triticum aestivum with powdery mildew resistance introduced from Hay aldia villosa L. In: Proceedings of the 8th International Vheat Genetics Symposium, Beijing, China (in press).

READER, S. M. AND MILLER, T. E. 1991. The introduction into bread wheat of a major gene for resistance to powdery mildew from wild emmer wheat. Euphytica, 53, 57-60.

SEARS, E. R. AND BRIGGLE, L. w. 1969. Mapping the gene Pm1 for resistance to Erysiphe graminis f. sp. tritici on chromosome 7A of wheat. Crop Sci., 9, 96-97.

THE, T. T., McINTOSH, R. A. AND BENNETT, F. G. A. 1979. Cytogenetical studies in wheat. IX. Monosomic analyses, telocentric mapping and linkage relationships of genes $\mathrm{Sr} 21, \mathrm{Pm} 4$ and Mle. Aust. J. Biol. Sci., 32, 115-125.
TOSA, Y. AND SAKAI, K. 1991. Analysis of the resistance of Aegilops squarrosa to the wheatgrass mildew fungus by using the gene-for-gene relationship. Theor. Appl. Genet., 81, 735-739.

VAlKoUn, J., Dostal, J. AND KUCEROVA, D. 1980. Triticum $\times$ Aegilops hybrids through embryo culture. In: Bajaj, Y. P. S. (ed.) Biotechnology in Agriculture and Forestry, 13, Wheat, pp. 152-166. Springer, Berlin.

VALKOUN, J., HAMMER, K., KUCEROVA, D. AND BARTOS, P. 1985. Disease resistance in the genus Aegilops L. - stem rust, leaf rust, stripe rust and powdery mildew. Kulturpflanze, 33, 133-153.

WANG, R. C., DONG, Y. AND ZHOU, R. 1993. Resistance to powdery mildew and barley yellow dwarf in perennial Triticeae species. Genet. Res. Crop Evol., 40, 171-176.

ZELLER, F. J. 1973. 1B/1R wheat-rye chromosome substitutions and translocations. In: Proceedings of the 4th International Wheat Genetics Symposium, Columbia, USA, pp. 209-221.

Zeller, F. J. AND FUChS, E. 1983. Cytologie und Krankheitsresistenz einer $1 \mathrm{~A} / 1 \mathrm{R}$ - und mehrerer $1 \mathrm{~B} / 1 \mathrm{R}$ - WeizenRoggen-Translokationssorten. Z. PflZücht., 90, 285-296.

ZELLER, F. J. AND HEUN, M. 1985. The incorporation and characterization of powdery mildew resistance from $\mathrm{Ae}$ gilops longissima in common wheat ( $T$. aestivum $\mathrm{L}$.) Theor. Appl. Genet., 71, 513-517.

ZELLER, F. J., STEPHAN, U. AND LUTZ, J. 1993. Chromosomal location of powdery mildew resistance genes in common wheat (Triticum aestivum L.). 1. Mlk and other alleles in Pm3 locus. Euphytica, 68, 223-229. 